\title{
Measurement of Radium Concentration and Radon Exhalation Rates of Soil Samples Collected from Selected Area of Aden Governorate, Yemen, Using Plastic Track Detectors
}

\author{
Fuad Abdo As-Subaihi ${ }^{1, ~ *, ~ S h a b a n ~ R a m d a n ~ H a r b ~}{ }^{2}$, Taher Abdullah Abdulgabar ${ }^{3}$ \\ ${ }^{1}$ Physics Department, Faculty of Science and Education-Sabir, Aden University, Aden, Yemen \\ ${ }^{2}$ Physics Department, Faculty of Science, South Valley University, Qena, Egypt \\ ${ }^{3}$ Chemistry Department, Faculty of Science and Education-Sabir, Aden University, Aden, Yemen
}

Email address:

fabdo11@yahoo.com (F.A. As-Subaihi),s.harb@ymail.com (S. R. Harb)

*Corresponding author

\section{To cite this article:}

Fuad Abdo As-Subaihi, Shaban Ramdan Harb, Taher Abdullah Abdulgabar. Measurement of Radium Concentration and Radon Exhalation Rates of Soil Samples Collected from Selected Area of Aden Governorate, Yemen, Using Plastic Track Detectors. International Journal of High Energy Physics. Vol. 6, No. 2, 2019, pp. 34-41. doi: 10.11648/j.ijhep.20190602.12

Received: July 26, 2019; Accepted: August 24, 2019; Published: December 17, 2019

\begin{abstract}
Radon exhalation rate from soil is one of the most important factors for evaluation of the environmental radon level. Solid State Nuclear Track Detectors (CR-39) has been widely used for the study of different aspects of radon emission from soil and others. In this paper, we are presenting the results of radon concentration, its exhalation rate and radium content in soil samples collected from different locations of northern part of Aden governorate, south of Yemen. The outdoor radon levels concentrations were found to vary from $264.59 \mathrm{~Bq} \mathrm{~m}^{-3}$ to $539.72 \mathrm{~Bq} \mathrm{~m} \mathrm{~m}^{-3}$ with a mean value of $369.29 \mathrm{~Bq} \mathrm{~m} \mathrm{~m}^{-3}$. The radon exhalation rate in terms of area and in terms of mass were found to vary from $460.08 \mathrm{mBq} \cdot \mathrm{m}^{-2} \cdot \mathrm{h}^{-1}$ to $938.47 \mathrm{mBq} \cdot \mathrm{m}^{-2} \cdot \mathrm{h}^{-1}$ with a mean value of $642.12 \mathrm{mBq} \cdot \mathrm{m}^{-2} \cdot \mathrm{h}^{-1}$ and from $25.99 \mathrm{mBq} \cdot \mathrm{m}^{-2} \cdot \mathrm{h}^{-1}$ to $53.02 \mathrm{mBqkg}{ }^{-1} \cdot \mathrm{h}^{-1}$ with a mean value of $36.28 \mathrm{mBqkg}^{-1} \cdot \mathrm{h}^{-1}$. The results of effective radium concentrations in these sites were found to vary from $3.44 \mathrm{Bqkg}^{-1}$ to $7.01 \mathrm{Bqkg}^{-1}$ with a mean value of $4.80 \mathrm{Bqkg}^{-1}$. The working level varied from $4.54 \mathrm{mWL}$ to $9.26 \mathrm{mWL}$ with a mean value of $6.34 \mathrm{mWL}$. The radon annual effective dose was varied from $0.049 \mathrm{mSvy}^{-1}$ to $0.100 \mathrm{mSvy}^{-1}$ with a mean value of $(0.068 \pm 0.18) \mathrm{mSvy}^{-1}$ for outdoor and from $0.20 \mathrm{mSvy}^{-1}$ to $0.40 \mathrm{mSvy}^{-1}$ with a mean value of $0.27 \mathrm{mSvy}^{-1}$ for indoor. The results indicate that the soil is quite safe for occupancies and to be used as building materials.
\end{abstract}

Keywords: Soil Samples, Aden Governorate, Radium Content, Radon Exhalation Rates, (Cr-39), Annual Absorbed Dose Rate

\section{Introduction}

Terrestrial radiation is due to various radioactive nuclides that are present in soil, water, air and their abundance changes depending on the geological and geographical features of region. The external exposure is caused by gamma rays emitted mainly by radionuclides of uranium ${ }^{238} \mathrm{U}$ and thorium ${ }^{232} \mathrm{Th}$ decay series as well as potassium ${ }^{40} \mathrm{~K}$. The internal exposure is caused by radon $\left({ }^{222} \mathrm{Rn}\right.$ and $\left.{ }^{220} \mathrm{Rn}\right)$ and its short-lived decay products. Radon is an alpha emitter that may be easily inhaled and its descendants may be deposited in tissues of the respiratory tract [1].

Radon is a natural inert radioactive tasteless and odorless gas, whose density is 7.5 times higher than that of air. Radon gas and its radioactive isotopes have special attention among the other naturally radioactive materials, because it has the largest amount of total annual effective dose to humane. There are two important natural occurring isotopes of radon; ${ }^{222} \mathrm{Rn}$, a direct product of ${ }^{226} \mathrm{Ra}$ in the ${ }^{238} \mathrm{U}$ series and ${ }^{220} \mathrm{Rn}$ a direct product of ${ }^{224} \mathrm{Ra}$ in the ${ }^{232} \mathrm{Th}$ series. Because radon has relatively long half-life enabling it to migrate quit significant distance before decaying and can be found in everywhere [2]. 
Radon comes from the natural decay of uranium that is found in nearly all soils. It appears mainly by diffusion processes from the point of origin following $\alpha$ - decay of ${ }^{226} \mathrm{Ra}$ in underground soil and rocks. It typically moves up through the ground to the air above and into homes through cracks and other holes in the foundation [3].

Radon is emitted from the ground and enters a home through cracks in walls, basement floors, foundations and other openings. Because radon comes from rock and soil, it can be found anywhere. Exposure to limited concentrations, like those found outdoors, is impossible to avoid. However, when radon gets trapped indoors, it may build up to dangerous concentrations, [4]. Long term exposures to radon via inhalation in closed rooms or caves or open air saturated with Radon gas is the cause for about $10 \%$ of all deaths from lung cancer [5]. The emission of radon per unit area per unit time is called exhalation rate and depends upon: (a) radium concentration in the material which in turn depends on the uranium concentration in the material, (b) emanation factor of radon from the material, (c) porosity and density of the material, and (d) diffusion coefficient of radon in the material [6]. Radon gas ionizes the ambient atmospheres both indoor and outdoor. The exhalation of radon from soil involves two mechanisms, the emanation and transport. These mechanisms are affected by many factors including the properties of the soil [7]. CR-39 polymer track detector is one of the most common polymer detectors that belong to SSNTDs. CR-39 polymer track detector (Poly-ally diglycol carbonate) is used in a wide range of different scientific and industrial technological applications such as radiological experiments, neutrons spectroscopy and radon dosimetry [8].

In the present study, we have used solid state nuclear track detectors (CR-39) for the analysis of radium content and radon exhalation rates in twenty six of soil samples collected from various locations in Aden city which is located in the South of Yemen on the Gulf of den. The location of this city has been determined using the Global Positioning System (GPS): Latitude: 1249'.468"N., Longitude: 4451'.708"E. The map of studied area is shown in Figure 1.

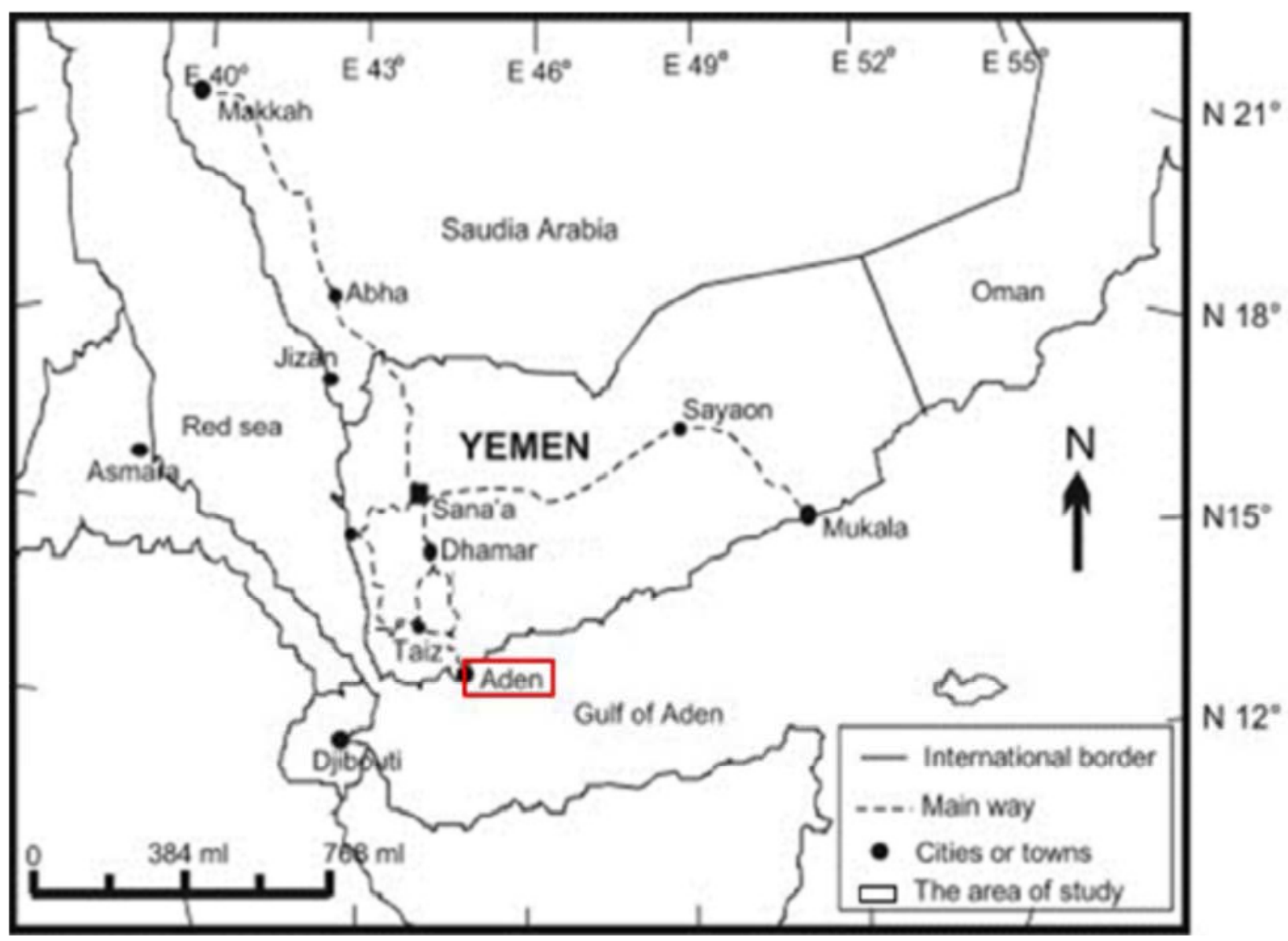

Figure 1. Sampling location map in Aden Governorate, Yemen.

\section{Materials and Methods}

Radium content and radon exhalation rates in the soil samples of study area were measured by following the sealed can technique [9]. The experimental set-up is shown in
Figure 2. Solid State Nuclear Track Detectors (SSNTD) with sheet thickness $300 \mu \mathrm{m}$ was used in this study, which is usually known as CR-39 [10]. Total of 26 soil samples were collected by the grab sampling method from different places of Aden governorate for the measurement. A dried and sieved sample $(250 \mathrm{~g})$ was placed at the bottom of a 
cylindrical sealed can of $11 \mathrm{~cm}$ height and $7 \mathrm{~cm}$ diameter. The dosimeters were stored (closed) for one month to reach secular equilibrium between radium and radon. After this period, CR-39 plastic detector $(1 \mathrm{~cm} \times 1 \mathrm{~cm})$, which was previously fixed by adhesive tape to the inside surface of a second identical cover was mounted quickly and closed the chamber [11]. Plastic can was closed well by its cover and was left for sixty days as exposure time, closed can techniques produced in Figure 1. CR-39 polymer detector registers alpha particles which emitted by decay of radium to radon gas as tracks. After the exposure time, CR-39 detectors were assembled from cans and chemically etched in $\mathrm{NaOH}$ solution $6.25 \mathrm{M}$ at $70^{\circ} \mathrm{C}$ to enlarge and appear the alpha tracks through time equal 8 hour $[12,13]$. After etching the CR-39 detectors were washed in distilled water and then dipped for few minutes in a 5\% acetic acid solution and washed again with distilled water and finally air dried. The track density was determined by using optical microscope at $640 \times$ magnification which calibrated before usages [14]. The background of CR-39 track detector was counted by optical microscope and subtracted from the count of all detectors [15, 4].

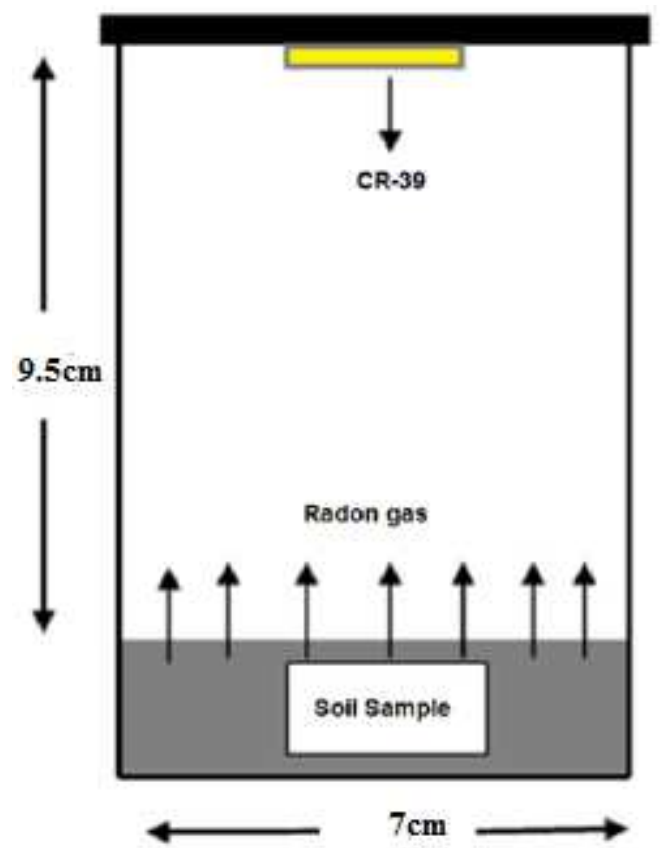

Figure 2. Shown of (CR-39 Plastic Detector) and a soil sample in a closed cylindrical plastic can.

\section{Theoretical Consideration}

The tracks density $(\rho)$ of the samples is measured using Equation (1): [16]

$$
\rho=\frac{\sum_{\mathrm{i}=1}^{\mathrm{n}} \mathrm{Ni}}{\mathrm{nxA}}
$$

Where $\rho:$ track density $\left(\right.$ track $\left./ \mathrm{mm}^{2}\right), \quad \sum_{\mathrm{i}=1}^{\mathrm{n}} \mathrm{Ni}=$ Total of the tracks, $n=$ Total number of field counted, $A=$ Area of the field of view. The track density $\rho$ (in track $/ \mathrm{cm}^{2}$ ) is related to the radon activity concentration $\mathrm{A}_{\mathrm{Rn}}\left(\mathrm{in} \mathrm{Bq} / \mathrm{m}^{3}\right)$ and the exposure time $\mathrm{T}$ by the formula: [17]

$$
\mathrm{C}_{R n}\left(\text { Bq. } \mathrm{cm}^{-3}\right)=\frac{\rho}{\mathrm{T} \eta}
$$

Where: $\eta$ : is the sensitivity factor of CR-39 plastic track detector, the value of $\eta$ is $6.59 \times 10^{-2}$ Traks.c $m^{-2} \cdot d a y^{-1} / B q . m^{-3}$ The calculated tracking density was converted to radon activity in $\mathrm{Bq} \cdot \mathrm{m}^{-3}$ using a calibration factor $(\mathrm{k})$, which is obtained from the date sheet of the manufacturer $\left(\mathrm{Bq} \cdot \mathrm{m}^{-3}\right) \cdot\left(\text { tracks } \cdot \mathrm{cm}^{-2} \cdot \mathrm{day}^{-1}\right)^{-1}$, where every track recorded per one $\mathrm{cm}^{-2}$ per day on the CR-39 detector is equivalent to $15.28 \mathrm{~Bq} \mathrm{~m}^{-3}[18,19]$. This is due to exposure to a variety of activities derived from radon gas and its progenies. The activity concentration of radon begins to increase with time $\mathrm{T}$, after the closing of the can, according to the relation: $[20,11]$

$$
\mathrm{C}_{R n}\left(\mathrm{Bqcm}^{-3}\right)=\mathrm{C}_{R a}\left(1-e^{-\lambda_{R n} T}\right)
$$

Where: $\mathrm{C}_{\mathrm{Ra}}$ (in $\mathrm{Bq} \cdot \mathrm{kg}^{-1}$ ) is the radium activity density of the sample and $\lambda_{R n}$ is the decay constant of ${ }^{222} \mathrm{Rn}(7.56 \times$ $\left.10^{-3} \mathrm{~h}^{-1}\right)$. Then, the tracks in the detector are used to measure the time-integrated value of the density of the track, as per expression (2). The total number of alpha disintegrations in unit volume of the can with a sensitivity $\eta$ during the exposure time $\mathrm{T}$, hence the track density observed is given by in equation (4): [21]

$$
\rho\left(\operatorname{Tr} . \mathrm{cm}^{-2}\right)=\eta \mathrm{C}_{R n} \mathrm{~T}_{e}
$$

Where $T_{e}$ denotes, by definition, the effective exposure time given by equation (5): [22]

$$
\mathrm{T}_{e} \text { (Days) }=\left[T-\frac{1}{\lambda_{R n}}\left(1-e^{-\lambda_{R n} T}\right)\right]
$$

Where $\mathrm{T}$ is time of exposure a day, hence the effective time calculated from Equation (5) was 24.5 days.

Radium concentration of the samples is calculated from the relations: $[11,23]$

$$
\mathrm{C}_{R a}(\mathrm{M})\left(\mathrm{Bq} \cdot \mathrm{kg}^{-1}\right)=\mathrm{C}_{R n}\left(\frac{\mathrm{V}}{\mathrm{M}}\right)
$$

Where $\mathrm{M}$ is the mass of the soil sample in $\mathrm{kg}$, $\mathrm{A}$ is the area of cross-section of the can in $\mathrm{m}^{2}$; $\mathrm{h}$ is the distance between the detector and top surface of the soil sample in meter.

The radon exhalation rate in terms of mass of the samples is calculated from the relation: [24, 25]

$$
\mathrm{E}_{\mathrm{M}}\left(\mathrm{Bqkg}^{-1} \mathrm{~d}^{-1}\right)=\frac{\mathrm{C}_{R n} \mathrm{~V} \lambda_{R n}}{\mathrm{M}\left[T-\frac{1}{\lambda_{R n}}\left(1-e^{-\lambda_{R n^{T}}}\right)\right]}
$$

Where: $E_{M}$ is the radon exhalation rate in terms of mass and $\mathrm{M}$ is the mass of the sample $(\mathrm{kg})$.

The radon exhalation rate in terms of area of the samples is calculated from the relations;

$$
\begin{gathered}
\mathrm{E}_{\mathrm{A}}\left(\mathrm{Bqm}^{-2} \mathrm{~d}^{-1}\right)=\frac{\mathrm{C}_{R n} \mathrm{~V}_{R n}}{\mathrm{~A}\left[T-\frac{1}{\lambda_{R n}}\left(1-e^{-\lambda_{R n} T}\right)\right]} \\
\mathrm{E}_{\mathrm{A}}\left(\mathrm{Bqm}^{-2} \mathrm{~d}^{-1}\right)=\mathrm{E}_{m}\left(\frac{M}{A}\right)
\end{gathered}
$$


Where: $\mathrm{E}_{\mathrm{A}}$ is the radon exhalation rate in terms of mass, $\mathrm{V}$ refers to the volume of the cup $\left(\mathrm{m}^{3}\right), T$ refers to the time of exposure (hour), and $\mathrm{A}$ is the area of cross-section of the cup $\left(38.46 \times 10^{-4} \mathrm{~m}^{2}\right)[24,25]$.

The annual effective dose equivalent, E, due to the activity in the soil was calculated using the following equation:

$$
\mathrm{E}\left(\mathrm{WLM} . \mathrm{Y}^{-1}\right)=\frac{8760 \times \mathrm{n} \times \mathrm{F} \times \mathrm{C}_{\mathrm{Rn}}}{170 \times 3700}
$$

Where $C_{R n}$ is in Bq. $m^{-3} ; n$ is the fraction of time spend $n=$ 0.2 for outdoor and $n=0.8$ for indoor, $\mathrm{F}$ is the equilibrium factor which equal to 0.42 as suggested by UNSCEAR [1], the number 8760 is refer to the time of hours per year and 170 is the number of hours per working month. For radon gas exposure in the present work, the effective dose equivalents were estimated by using a conversion factor of $6.3 \mathrm{mSv} / \mathrm{WLM}[2,26]$.

The working levels of the samples is calculated from the relations: $[27,28]$

$$
\mathrm{WL}=\frac{C_{R n} \cdot \mathrm{F}}{3700}
$$

Where, $\mathrm{C}_{\mathrm{Rn}}$ is radon concentration in $\mathrm{Bqm}^{-3}$ and $\mathrm{F}$ is the equilibrium factor for radon has been taken as 0.42 as suggested by [3, 29].

\section{Result and Discussion}

Table 1 list the track density and radon concentrations, mass exhalation rate and area exhalation rate, in samples taken from selected area of northern part of Aden governorate, South of Yemen. The radon concentration varies from $(264.59-539.72) \mathrm{Bq} / \mathrm{m}^{3}$ with a mean value of $(369.29 \pm 15.55) \mathrm{Bq} / \mathrm{m}^{3}$. It is notices that, radon concentration in the studied area are within the recommended limits of ICRP and closed or less than the nearby countries $[30,31]$. The radon exhalation rate in terms of area and in terms of mass varies from $(460.08-938.47) \mathrm{mBq} \cdot \mathrm{m}^{-2} \cdot \mathrm{h}^{-1}$ with a mean value of $(642.12 \pm 27.04) \mathrm{mBq} \cdot \mathrm{m}^{-2} \cdot \mathrm{h}^{-1}$ and (25.99-53.02) $\mathrm{mBq} \cdot \mathrm{kg}^{-1} \cdot \mathrm{h}^{-1}$ with a mean value of $(36.28 \pm 4.14) \mathrm{mBq} \cdot \mathrm{kg}^{-1} \cdot \mathrm{h}^{-1}$. Radon exhalation rates observed in the current study are also quite below the world average of $57,600 \mathrm{mBq} \cdot \mathrm{m}^{-2} \cdot \mathrm{h}^{-1}$ $\left(0.016 \mathrm{~Bq} \cdot \mathrm{m}^{2} \cdot \mathrm{s}^{-1}\right)$ and hence will not cause any health hazards to residents $[32,11]$. It is notice from table 3 that the effective radium content of soil sample varies from (3.447.01) $\mathrm{Bqkg}^{-1}$ with a mean value of $4.80 \mathrm{Bqkg}^{-1}$. The results of exhalation rates and effective radium content in soil sample are in agreement with the results of A. Subber et al. [2, 19], whom used the same method for measurement of those parameters in soil samples. The radium content is lower than the permitted value of $370 \mathrm{~Bq} \cdot \mathrm{Kg}^{-1}$ as recommended by Organization for Economic Cooperation and Development (OECD) [33]. The calculated values of working level (WL), the outdoor and indoor annual effective dose were given by table 3. The working level varied from $4.54 \mathrm{mWL}$ to $9.26 \mathrm{mWL}$ with a mean value of $6.34 \mathrm{mWL}$. The radon annual effective dose was varied from $0.049 \mathrm{mSvy}^{-1}$ to $0.100 \mathrm{mSvy}^{-1}$ with a mean value of $0.068 \mathrm{mSvy}^{-1}$ for outdoor and from 0.20 $\mathrm{mSvy}^{-1}$ to $0.40 \mathrm{mSvy}^{-1}$ with a mean value of $0.27 \mathrm{mSvy}^{-1}$ for indoor. The outdoor and indoor annual effective dose lower than the normal background level of $1.10 \mathrm{mSvy}^{-1}$ as quoted by [1]. Thus, results reveal that the area is safe as far the health hazard effects. Figures 3 and 4 have shown the distribution of Activity Concentration of radon and radium content in the different soil samples of Aden governorate, south of Yemen. While figures 5 and 6 have shown the distribution values of mass exhalation rates and surface exhalation rates of radon for all soil samples, respectively, These figures and Tables 2 and 3 show that the value of radium content and radon exhalation rates for soil samples are less than the values reported by many researchers [1,2, and 5].

Table 1. The value of calculated track density and radon concentrations, in

\begin{tabular}{|c|c|c|}
\hline Samples Number & $\rho \times 103$ in $\operatorname{Tr} \mathrm{cm}^{-2} \mathrm{~d}^{-1}$ & Rn concentration in $\left(B q \cdot \mathrm{m}^{-3}\right)$ \\
\hline 1 & 11.502 & 296.97 \\
\hline 2 & 10.524 & 271.72 \\
\hline 3 & 10.752 & 277.61 \\
\hline 4 & 12.162 & 314.01 \\
\hline 5 & 14.364 & 370.87 \\
\hline 6 & 11.424 & 294.96 \\
\hline 7 & 13.696 & 353.62 \\
\hline 8 & 16.960 & 437.89 \\
\hline 9 & 13.928 & 359.61 \\
\hline 10 & 12.708 & 328.11 \\
\hline 11 & 10.248 & 264.59 \\
\hline 12 & 12.68 & 327.39 \\
\hline 13 & 13.416 & 346.39 \\
\hline 14 & 16.392 & 423.23 \\
\hline 15 & 14.448 & 373.04 \\
\hline 16 & 14.808 & 382.33 \\
\hline 17 & 18.016 & 465.16 \\
\hline 18 & 12.992 & 335.44 \\
\hline 19 & 10.88 & 280.91 \\
\hline 20 & 12.6 & 325.32 \\
\hline 21 & 20.904 & 539.72 \\
\hline 22 & 20.104 & 519.07 \\
\hline 23 & 17.384 & 448.84 \\
\hline 24 & 19.704 & 508.74 \\
\hline 25 & 12.712 & 328.21 \\
\hline 26 & 16.568 & 427.77 \\
\hline Minimum & 10.248 & 264.59 \\
\hline Maximum & 20.90 & 539.72 \\
\hline Mean value & 14.30 & $369.29 \pm 15.55$ \\
\hline
\end{tabular}
samples taken from selected region in Aden Governorate. 


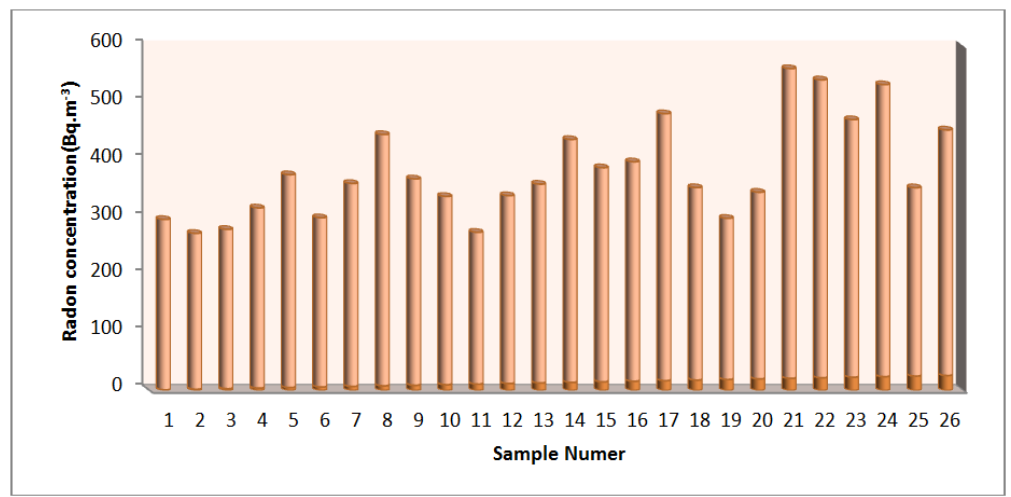

Figure 3. Shown of the Activity Concentration of radon for different soil samples in Aden Governorate, Yemen.

Table 2. The value of calculated Radon mass and area exhalation rate in soil samples taken from selected region in Aden Governorate, Yemen.

\begin{tabular}{|c|c|c|}
\hline Samples Number & Radon mass Exhalation rate in $\mathrm{mBq} \cdot \mathrm{kg}^{-1} \cdot \mathrm{h}^{-1}$ & Radon Exhalation Rate per unit are $\mathrm{mBq} \cdot \mathrm{m}^{-2} \cdot \mathrm{h}^{-1}$ \\
\hline 1 & 29.17 & 516.38 \\
\hline 2 & 26.69 & 472.47 \\
\hline 3 & 27.27 & 482.70 \\
\hline 4 & 30.85 & 546.01 \\
\hline 5 & 36.43 & 644.86 \\
\hline 6 & 28.98 & 512.87 \\
\hline 7 & 34.74 & 614.87 \\
\hline 8 & 43.02 & 761.41 \\
\hline 9 & 35.33 & 625.29 \\
\hline 10 & 32.23 & 570.52 \\
\hline 11 & 25.99 & 460.08 \\
\hline 12 & 32.16 & 569.26 \\
\hline 13 & 34.03 & 602.30 \\
\hline 14 & 41.58 & 735.91 \\
\hline 15 & 36.65 & 648.63 \\
\hline 16 & 37.56 & 664.79 \\
\hline 17 & 45.69 & 808.82 \\
\hline 18 & 32.95 & 583.27 \\
\hline 19 & 27.59 & 488.45 \\
\hline 20 & 31.96 & 565.67 \\
\hline 21 & 53.02 & 938.47 \\
\hline 22 & 50.99 & 902.56 \\
\hline 23 & 44.09 & 780.44 \\
\hline 24 & 49.98 & 884.60 \\
\hline 25 & 32.24 & 570.69 \\
\hline 26 & 42.03 & 743.81 \\
\hline Minimum & 25.99 & 460.08 \\
\hline Maximum & 53.02 & 938.47 \\
\hline Mean value & $36.28 \pm 4.14$ & $642.12 \pm 27.04$ \\
\hline
\end{tabular}

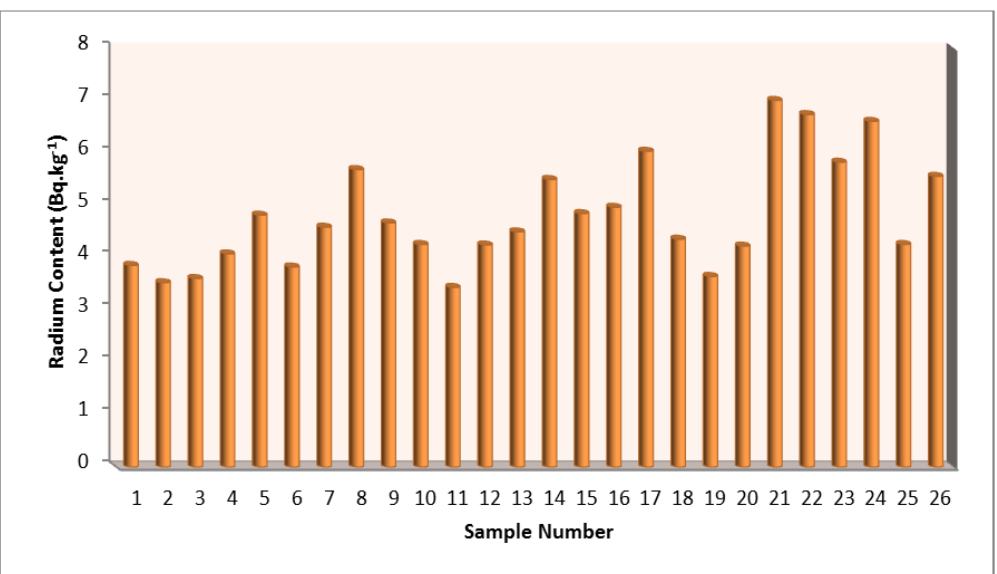

Figure 4. Shown of the Effective radium content for different soil samples in Aden Governorate, Yemen. 


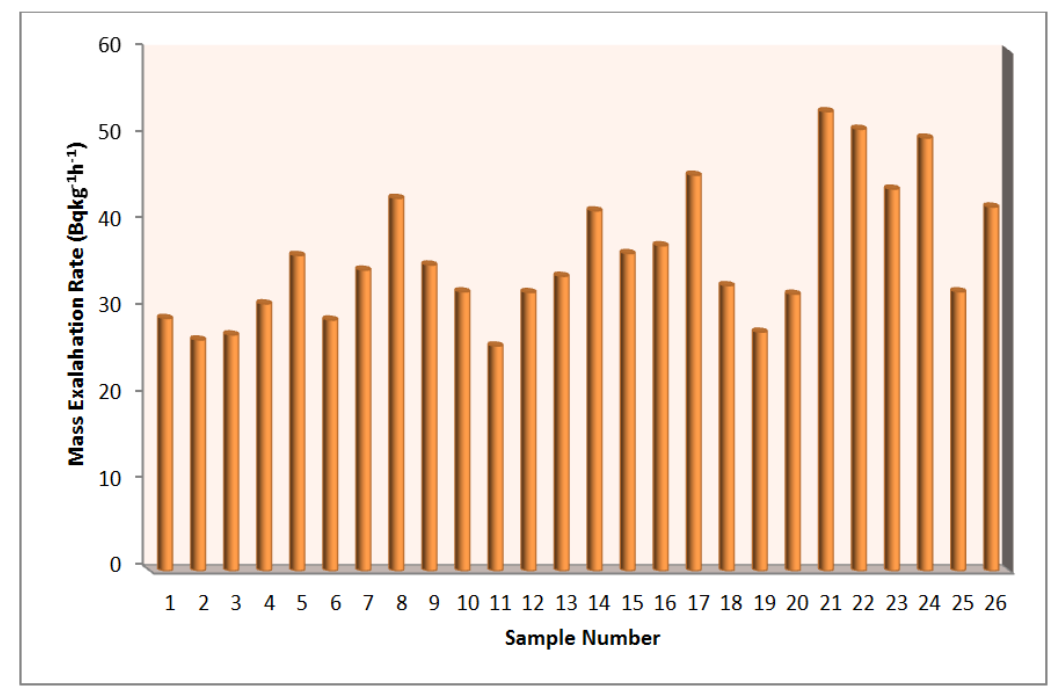

Figure 5. Shown of the Mass exhalation rates of radon for different soil samples in Aden Governorate, Yemen.

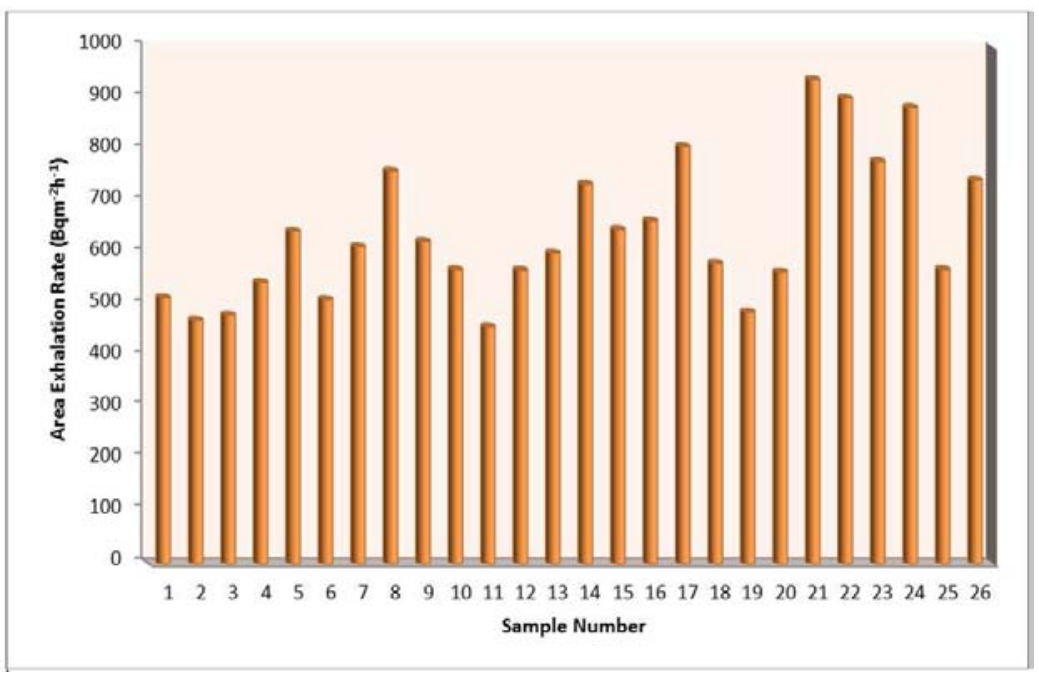

Figure 6. Shown of the Area exhalation rates of radon for different soil sample in Aden Governorate, Yemen.

Table 3. The value of calculated Effective radium, outdoor and indoor effective dose and working level, in samples taken from selected region in Aden Governorate, Yemen.

\begin{tabular}{|c|c|c|c|c|}
\hline Samples Number & Effective Ra in Bq.kg ${ }^{-1}$ & Outdoor effective dose in $\mathrm{mSvy}^{-1}$ & indoor effective dose in $\mathrm{mSvy}^{-1}$ & MWL \\
\hline 1 & 3.86 & 0.055 & 0.22 & 5.09 \\
\hline 2 & 3.53 & 0.050 & 0.20 & 4.66 \\
\hline 3 & 3.61 & 0.051 & 0.21 & 4.76 \\
\hline 4 & 4.08 & 0.058 & 0.23 & 5.39 \\
\hline 5 & 4.82 & 0.069 & 0.27 & 6.36 \\
\hline 6 & 3.83 & 0.055 & 0.22 & 5.06 \\
\hline 7 & 4.59 & 0.066 & 0.26 & 6.07 \\
\hline 8 & 5.69 & 0.081 & 0.32 & 7.51 \\
\hline 9 & 4.67 & 0.067 & 0.27 & 6.17 \\
\hline 10 & 4.26 & 0.061 & 0.24 & 5.63 \\
\hline 11 & 3.44 & 0.049 & 0.20 & 4.54 \\
\hline 12 & 4.25 & 0.061 & 0.24 & 5.62 \\
\hline 13 & 4.50 & 0.064 & 0.26 & 5.94 \\
\hline 14 & 5.50 & 0.078 & 0.31 & 7.26 \\
\hline 15 & 4.85 & 0.069 & 0.28 & 6.40 \\
\hline 16 & 4.97 & 0.071 & 0.28 & 6.56 \\
\hline 17 & 6.04 & 0.086 & 0.34 & 7.98 \\
\hline 18 & 4.36 & 0.062 & 0.25 & 5.76 \\
\hline 19 & 3.65 & 0.052 & 0.21 & 4.82 \\
\hline 20 & 4.23 & 0.060 & 0.24 & 5.58 \\
\hline 21 & 7.01 & 0.100 & 0.40 & 9.26 \\
\hline
\end{tabular}




\begin{tabular}{|c|c|c|c|c|}
\hline Samples Number & Effective $\mathrm{Ra}$ in $\mathrm{Bq} \cdot \mathrm{kg}^{-1}$ & Outdoor effective dose in $\mathrm{mSvy}^{-1}$ & indoor effective dose in $\mathrm{mSvy}^{-1}$ & M WL \\
\hline 22 & 6.74 & 0.096 & 0.38 & 8.91 \\
\hline 23 & 5.83 & 0.083 & 0.33 & 7.70 \\
\hline 24 & 6.61 & 0.094 & 0.38 & 8.73 \\
\hline 25 & 4.26 & 0.061 & 0.24 & 5.63 \\
\hline 26 & 5.56 & 0.079 & 0.32 & 7.34 \\
\hline Minimum & 3.44 & 0.049 & 0.20 & 4.54 \\
\hline Maximum & 7.01 & 0.100 & 0.40 & 9.26 \\
\hline
\end{tabular}

\section{Conclusions}

The main aim of this study was to determine radon concentration and exhalation rate in the soil samples using solid state nuclear track detectors. The measured values of radon concentration and exhalation rate generally in the recommended limit by the world wide safe limit given by UNSCEAR 2000. Most of the indoor radon values lie in the range of action levels from 200 to $600 \mathrm{Bqm}^{-3}[34,35]$. The average values of radon concentrations in the soil samples are lower than the recommended limit $800 \mathrm{Bqm}^{-3}$ which, reported by WHO, 1993. The effective radium distribution in the soil samples varies from point to point in the same district. Its value is found to be much below the hazard limit. The obtained results can be used as reference information to assess any changes in the radioactive background level due to geological processes in the investigated area. Finally, our results clearly show that the area under investigation is safe as far as the health hazards of radon are concerned.

\section{Conflicts of Interest}

The authors declare no conflict of interest.

\section{References}

[1] UNSCEAR (United Nation Scientific Committee on the Effects of Atomic Radiation) (2000) Sources and Effects of Ionizing Radiation, United Nations: New York, United Nation.

[2] A. Subber et al., (2017) Measurement of Radium Concentration and Radon Exhalation Rates of Soil Samples Collected From Selected Area of Basrah Governorate, Iraq Using Plastic Track Detectors, J. Rad. Nucl. Appl. 2, No. 1, 11-15. Ref.: http://dx.doi.org/10.18576/jrna/020102.

[3] Khalil M. Thabayneh, (2016) Determination of Alpha Particles Concentration in Some Soil Samples and the Extent of Their Impact on Health, Sains Malaysiana 45 (5): 699-707.

[4] Nabil. N. Al-Zubaidy, Abdallah Husain Almohammad, (2016) The Relationship between Radon Concentrations in the Soil and Air of Houses in Alal Region, Jordan, IOSR Journal of Applied Physics (IOSR-JAP) e-ISSN: 2278-4861. Volume 8, Issue 6 Ver. II, PP 21-25. Ref.: DOI: 10.9790/48610806022125 .

[5] Pankaj Bala et al., (2017) Measurement of radon exhalation rate in various building materials and soil samples, J. Earth Syst. Sci. 126: 31. Ref.: DOI: 10.1007/s12040-017-0797-z.

[6] S. S. Althoyaib and A. El-Taher. (2016) Natural Radioactivity levels of Radon, Radium and the associated health effects in Drinking water Consumed in Qassim area, Saudi Arabia. Journal of Environmental Science and Technology, 9 (2) 208213.

[7] W. R. Alharbi, Adel G. E. Abbady and A. El-Taher. (2015) Radon Concentrations Measurement for groundwater Using Active Detecting Method, American Scientific Research Journal for Engineering, Technology, and Sciences (ASRJETS), 14 (1) 1-11.

[8] Zaki, M. F., Elshaer, Y. H., Doaa, H. T., (2017) Studying the structural, optical, chemical and electrochemical etching changes of CR-39 for dosemetric applications. Radiation Protection Dosimetry, 1-8. Ref.: doi: 10.1093/rpd/ncx040.

[9] Bhardwaj M. K. et al., (2013) Measurement of Radium Content and Radon Exhalation Rates in Soil Samples of Mekelle City, Ethiopia, I. J. S. N., vol. 4 (1): 182-184.

[10] Abdalsattar Kareem Hashim, (2013) Measurement of radium content and radon exhalation rates in soil samples of AlHindiyah City. Journal of Kerbala University, vol. 11 No. 3 Scientific.

[11] Mohsen B Challan and Atteyat A Labib. (2018) Radiological assessment of exposure doses and radon exhalation rates of building materials in Saudi Arabia, J Radiol Oncol.; 2: 012021. https://doi.org/10.29328/journal.jro.1001017.

[12] Hala M. Hassan, Doaa H. Shabaan, (2015) Physico-chemical and radon analysis of drinking water available in SamtahJazan city Southwest of Saudia Arabia. Journal of Desalination and Water Treatment. 57, 19140-19148.

[13] Tayseer, I. N., Ayman, M. A. (2017) The Activity Concentrations of 222Rn in Some Ground Water Wells, Najran City, Saudi Arabia. Nuclear Technology \& Radiation Protection. 32, No. 2, 166-173.

[14] Kumar A, Chauhan RP, Joshi M, Sahoo BK. (2014) Modeling of indoor radon concentration from radon exhalation rates of building materials and validation through measurements. J Environ Radioact; 50-55. Ref.: https://goo.gl/EnVZTP

[15] Abo-Elmagd M., Mansy M., Eissa H. M. and El-Fiki M. A. (2006). Major parameters affecting the calculation of equilibrium factor using SSNTDs measured track densities. Radiat. Meas., 41, 235-240.

[16] Morelli, D., Catalano, R., Filincieri, R., Immé, G., Mangano, G., (2015). Radon exhalation rate in south-east Sicily building materials. The European Physical Journal Special Topics, 224 (4), 605-610.

[17] Nisar Ahmad et al. (2014) Measurement of Radon Exhalation Rate, Radium Activity and Annual Effective Dose From Bricks and Cement Samples Collected From Dera Ismail Khan, American Journal of Applied Sciences 11 (2): 240-247. 
[18] Al-Saadi, A.J., Hashim, A.K., Musa, H.J. (2015). Determination of Radium and Radon Exhalation Rates in Soil Samples Collected from Kerbala Governorate. International Journal of Physics, 3 (5), 208-212.

[19] A. R. H. Subber, H. N. Noori, F. N. Ali, H. J. Jabbar and M. K. Khodier, (2015) Constructasa simple radon chamber for measurement of radon detectors calibration factors, Pelagia Research Library, Advances in Applied Science Research, 6 (2): 128-131.

[20] M. Shakir Khan, A. H. Naqvi, A. Azam, D. S. Srivastava, (2011) Radium and radon exhalation studies of soil, Iran. J. Radiat. Res., 8 (4) 207-210.

[21] Misdaq MA, Elouardi B, Ouguidi J. (2017) Rn-222, Rn-220 and their progenies measured in the air of different dwellings and workplaces and resulting alpha radiation doses to the eyes of individuals. Health Physics. 113: 363-374.

[22] Rastogi N, Singh I. (2017) Levels of natural radioactivity in environment in residential area of Moradabad District, Western Uttar Pradesh. Pollution. 3; 1-7. Ref.: https://goo.gl/RWjHKT.

[23] Abu-Jarad F, Fremlin J H and Bull R A (1980) Study of radon emitted from building materials using plastic track detectors; Phys. Med. Biol., 25 (4) 683-694.

[24] Thabayneh, K. M., (2016) Determination of Alpha Particles Concentration in Some Soil Samples and the Extent of Their Impact on Health. Sains Malaysiana, 45 (5), 699-707.

[25] Ali Abid Abojassim, (2017) Alpha Particles Concentrations from Some Soil Samples of Al-Najaf (IRAQ), POLISH Journal of Soil Science Vol. 1/2, PL ISSN 0079-2985. Ref.: DOI: $10.17951 / \mathrm{pjss} / 2017.50 .2 .249$.

[26] H. A. Yousef et al., (2015) Radon Exhalation Rate in Surface Soil of Graduate's Villages in West Nile Delta, Egypt, Using Can Technique, International Journal of Recent Scientific Research Vol. 6, Issue, 4, pp. 3440-3446. Ref.: http://dx.doi.org/10.4236/wjnst.2015.53014.
[27] Nsiah-Akoto I., Fletcher J. J, Oppon O. C., and Andam A. B., (2011). Indoor radon levels and the associated effective dose rate determination at dome in the greater Accra Region of Ghana., Research Journal of Environmental and Earth Sciences, 3 (2), 24-30.

[28] H. A. Youssef et al., (2015) Measurement of Radon Exhalation Rate in Some Building Materials Using Nuclear Track Detectors, World Journal of Nuclear Science and Technology, $5,141-148$.

[29] Mamta Gupta, Mahur A. K., Sonkawade and Verma K. D. (2011). Monitoring of indoor radon and its progeny in dwellings of Delhi using SSNTDs. Advances in Applied Science Res., 2 (5), 421-426.

[30] L. Vaillant and C. Bataille, Management of radon: a review of ICRP recommendations, J. Radiol. Prot., 32, R1- R12, 2012.

[31] S. Al-Ghamdi and M. S. Al-Garawi, (2011) Estimation of Soil Radon Concentration in Al-Qateef's Date Palm Farms, Saudi Arabia, Conference Proceedings, DOI: 10.1063/1.3638114, 1370 (1).

[32] Singh H, Singh J, Singh S, Bajwa BS. (2008) Radon exhalation rate and uranium estimation study of some soil and rock samples from Tusham ring complex, India using SSNTD technique. Radiation Measurements, 459-462. Ref.: https://goo.gl/jWW1FHb.

[33] OECD. Exposure to radiation from the natural activity in building materials. Organisation for Economic Co-operation Development. Nuclear Energy Agency. 1979.

[34] ICRP, International Commission of Radiological Protection statement on radon, Ref. 00/902/09, 2009.

[35] Singh Surinder and Prasher Sangeeta, (2004). The etching and structural studies of gamma irradiated induced effects in CR39 plastic track recorder. Nucl. Instr. Meth. Phys. Research B, 222, 518-524.

[36] WHO, 1993. Guidelines for drinking water quality. World Health Organization, Vol., 2, Geneva, 1993. 